\title{
CRIMINOLOGICAL CHARACTERISTICS OF THE ORGANIZED CRIME: QUANTITATIVE AND QUALITATIVE INDICATORS
}

\section{КРИМІНОЛОГІЧНА ХАРАКТЕРИСТИКА ОРГАНІЗОВАНОЇ ЗЛОЧИННОСТІ: КІЛЬКІСНІ ТА ЯКІСНІ ПОКАЗНИКИ}

\section{Svetlana Shalgunova ${ }^{1}$ Taisiya Shevchenko ${ }^{2}$}

DOI: https://doi.org/10.30525/978-9934-588-53-2-42

Abstract. In the article, within the criminological characteristics, an in-depth analysis of the state, dynamics and structure of organized crime in Ukraine is conducted. Official statistical information of the Prosecutor General's Office of Ukraine on criminal offenses within organized groups and criminal organizations has been kept since 2016, so the quantitative characteristics was carried out for 2016-2019. In particular, the quantitative analysis was conducted in the following areas: state of organized crime over the mentioned years and its comparative characteristics. Also, it is conducted an analysis of criminal offenses, which are committed the most frequently by organized groups and criminal organizations. The peculiarities of criminal liability, which is provided for the special form of complicity in the Criminal Code of Ukraine, are considered: organized groups and criminal organizations that form organized crime. The conducted analysis of organized crime made it possible to identify the problems of the state of organized crime, which will allow effective implementation of countermeasures in the practical activity of special subjects of counteraction. Methodology. In the course of the research, philosophical and dialectical laws and categories, as well as logical principles and techniques were used, which are necessary and sufficient to achieve the goal and to find a new subject of study of the specified topic. In addition to general methods, special criminological methods, namely mathematical and statistical, were applied.

\footnotetext{
${ }^{1}$ Candidate of Juridical Sciences, Associate Professor, Head of the Department of criminal-legal disciplines, Dnipropetrovsk State University of Internal Affairs, Ukraine ${ }^{2}$ Senior lecturer at the Department of criminal-legal disciplines, Dnipropetrovsk State University of Internal Affairs, Ukraine
} 
Structure. The structure of the scientific article consists of five sections: an introductory part, which defines the purpose of the research, goals, novelty and significance for further theoretical research and implementation in the practice of combating crime. The presentation of the basic material of the conducted research consists of the detailed analysis of quantitative indicators of organized crime, comparison with previous periods and general state of crime. The conducted analysis clearly demonstrates the state of organized crime during the years 2016-2020 in form of diagrams. The analysis of the provisions of the Criminal Code of Ukraine regarding the peculiarities of criminal liability for criminal offenses committed within organized groups and criminal organizations made it possible to draw conclusions and to outline prospects for further research on organized crime.

\section{1. Вступ}

Організована злочинність має високий ступінь суспільної небезпеки, порівняно з іншими видами злочинності. Саме тому, багато уваги приділяється заходам протидії організованій злочинності. Пік боротьби з організованою злочинністю в Україні припав на 1990 роки, які дали позитивні результати. Однак, злочинність має мінливий та перехідний характер, тому актуальним питанням залишається проведення дослідження стану злочинності для впровадження в практичний досвід попереджувальних заходів протидії організованій злочинності. Питаннями протидії організованій злочинності приділяли увагу: Корнієнко В. М., Голіна В. В., Джужа О. М., Погорецький М. А., Даньшин I. М., Грохольський В. Л., Жаровська Г. П. та інші. Незважаючи на проведені дослідження феномену існування організованої злочинності в Україні, на сьогодні організована злочинність має здатність трансформуватися і розвиватися, пристосовуючись до сучасності, тому виникає необхідність проведення дослідження кількісно-якісних показників організованої злочинності в Україні, щоб мати змогу бути на крок попереду у заходах протидії.

Метою статті є надання, в рамках кримінологічної характеристики, розгорнутого аналізу стану, динаміки та структури організованої злочинності в Україні. Офіційна статистична інформація Генеральної прокуратури України щодо вчинених кримінальних правопорушень у складі організованих груп (далі - ОГ) та злочинних організацій 
(далі - 30) ведеться з 2016 року. Враховуючи це, кількісний аналіз буде проведено за 2016-2019 роки за наступними напрямками: порівняльна характеристика стану організованої злочинності та проведення аналізу кримінальних правопорушень, які найбільш часто вчиняються в складі організованих груп та злочинних організацій. Також, розгляду підлягатимуть питання щодо особливостей кримінальної відповідальності, яка передбачена за спеціальну форму співучасті в Кримінальному кодексі України (далі - КК України): організовані групи та злочинні організації, які складають організовану злочинність. Проведений аналіз організованої злочинності надасть можливість наявно побачити проблеми стану організованої злочинності, сформувати заходи протидії їй та, з урахуванням проведеного дослідження та зроблених висновків, - визначити перспективи подальшого дослідження організованої злочинності.

\section{2. Кількісні та якісні показники організованої злочинності в Україні}

Так, за статистичними даними Генеральної прокуратури України, окремий облік організованої злочинності ведеться з 2016 року.

За 2016 рік в Україні виявлено: всього - 136 організованих груп та злочинних організацій, 3 низ організованих груп - 133, злочинних організацій - 3; з них мають корумповані зв'язки 16 груп, транснаціональні - 4. Чисельність груп більше складає 3-10 осіб. Всього у 2016 році виявлено осіб у складі організованих груп та злочинних організацій - 598. Сфери діяльності осіб: етнічна - 29; бюджетна 28; фінансово-кредитна - 29; пов'язана із земельними правовідносинами - 11; пов'язана із вугільною промисловістю - 11 .

За 2017 рік в Україні виявлено: всього - 210 організованих груп та злочинних організацій, з них організованих груп - 205, злочинних організацій - 5; з них мають корумповані зв'язки 25 груп, транснаціональні - 11. Чисельність груп більше складає 3-10 осіб, організованих груп - 85 осіб, злочинних організацій -4 . Всього у 2017 році виявлено осіб у складі організованих груп та злочинних організацій - 949, у тому числі 68 осіб у складі злочинної організації. Сфери діяльності осіб: етнічна - 35; бюджетна - 40; фінансово-кредитна - 17; пов'язана із земельними правовідносинами - 6; пов'язана із вугільною промисловістю - 3, у сфері нафтогазової промисловості - 28 . 
За 2018 рік в Україні виявлено: всього - 288 організованих груп та злочинних організацій, 3 них організованих груп - 276, злочинних організацій - 12; з них мають корумповані зв'язки 21 група, транснаціональні - 7. Чисельність груп більше складає 3-10 осіб, організованих груп - 120 осіб, злочинних організацій - 11, від 11 до 20 осіб - 7, 3 них злочинні організації - 2. Всього у 2018 році виявлено осіб у складі організованих груп та злочинних організацій -1429 , у тому числі 168 осіб у складі злочинної організації. Сфери діяльності осіб: етнічна - 69; бюджетна - 86, у тому числі у складі злочинних організацій - 15 ; у банківській системі -25 ; фінансово-кредитна -19 , у тому числі у складі злочинних організацій - 9; пов'язана із земельними правовідносинами -5 ; пов'язана із вугільною промисловістю -23 , у сфері нафтогазової промисловості - 17.

3а 2019 рік в Україні виявлено: всього - 293 організованих груп та злочинних організацій, 3 них організованих груп - 277, злочинних організацій - 16; 3 них мають корумповані зв'язки 29 група, транснаціональні - 6. Чисельність груп більше складає 3-10 осіб організованих груп - 118 осіб, злочинних організацій - 11, від 11 до 20 осіб - 5, 3 них злочинні організації - 3. Всього у 2019 році виявлено осіб у складі організованих груп та злочинних організацій -1428 , у тому числі 235 осіб у складі злочинної організації. Сфери діяльності осіб: етнічна - 50; бюджетна -89 , у тому числі у складі злочинних організацій - 9; у банківській системі - 14 ; фінансово-кредитна -5 , у тому числі у складі злочинних організацій - 1 ; пов'язана із земельними правовідносинами - 6; пов'язана із вугільною промисловістю - 2, у сфері нафтогазової промисловості - 11 [1].

Слід зазначити, що за останні чотири роки, ми можемо побачити негативну динаміку стану організованої злочинності, яка має тенденцію до щорічного збільшення. Якісна характеристика організованої злочинності як структурна частина загальної кількості злочинності складає взагалі невелику частку. Так, у 2016 році питома вага організованої злочинності склала $0,02 \%$ від загальної кількості вчинених злочинів; у 2017 році питома вага ОГ та 30 склала $0,04 \%$; у 2018 році питома вага склала вже $0,06 \%$, а у 2019 році $-0,07 \%$. Таким чином, на фоні загального зниження рівня злочинності у 2018-2019 роках, рівень організованої злочинності збільшився. Окрім того, це стосується як 


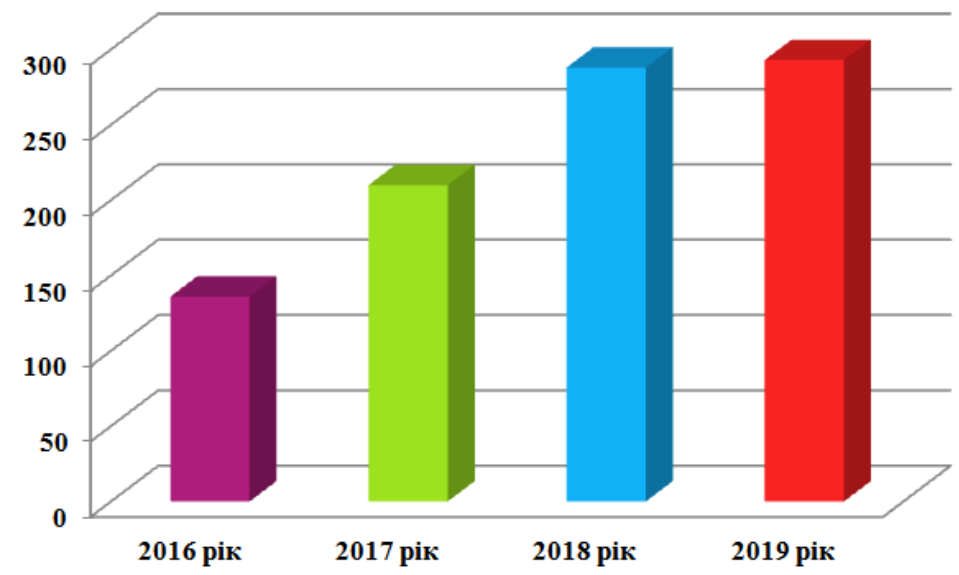

Діаграма 1. Співвідношення кількісних показників облікованих організованих груп та злочинних організацій за період 2016-2019 роки

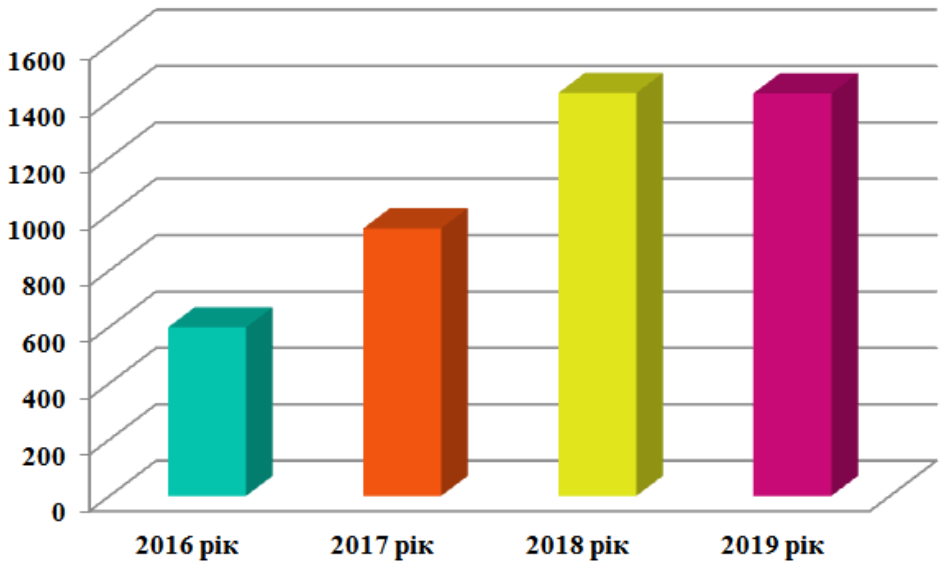

Діаграма 2. Співвідношення кількісних показників осіб, які вчинили злочини у складі організованих груп та злочинних організацій за період 2016-2019 роки 
самих груп, так і кількості їх учасників. Отже, актуальною визначена тема залишається й на сьогоднішній день. Відсоток організованої злочинності є невеликим, порівняно, наприклад, із злочинами проти власності, питома вага яких, за вказаний період, складала 58-68\% від загальної кількості вчинених злочинів. Однак, організована злочинність несе в собі в рази більше суспільної небезпеки ніж інші види злочинності, а враховуючи щорічну негативну динаміку, ми можемо припустити до якої частки може дійти рівень організованої злочинності, якщо не проводити ефективні заходи протидії.

\section{3. Поняття організованої злочинності}

\section{та кримінальна відповідальність за особливу форму співучасті}

Визначення організованої злочинності наведено в Законі України «Про організаційно-правові основи боротьби з організованою злочинністю», і визначено як сукупність злочинів, що вчиняються у зв'язку 3 створенням та діяльністю організованих злочинних угруповань [2].

В КК України визначення організованої групи та злочинної організації як форм співучасті надано в ч. 3 статті 28 КК України. Так, злочин визнається вчиненим організованою групою, якщо в його готуванні або вчиненні брали участь декілька осіб (три і більше), які попередньо зорганізувалися у стійке об'єднання для вчинення цього та іншого (інших) злочинів, об'єднаних єдиним планом з розподілом функцій учасників групи, спрямованих на досягнення цього плану, відомого всім учасникам групи.

Частина 4 статті 28 КК України закріплює визначення злочинної організації за наступними ознаками: стійкість, ієрархічність, п’ять i більше осіб, члени об'єднання або структурні частини об'єднання за попередньою змовою зорганізувалися для спільної діяльності з метою безпосереднього вчинення тяжких або особливо тяжких злочинів учасниками цієї організації, або керівництва чи координації злочинної діяльності або інших осіб, або забезпечення функціонування як самої злочинної організації, так і інших злочинних груп [3]. Окрім цього, ст. 27 КК України закріплює визначення організатора організованої групи. Стаття 30 КК України визначає кримінальну відповідальність організатора та учасників організованої групи або злочинної організації. Пункт 2 ч. 1 ст. 67 КК України визначає вчинення злочину гру- 
пою осіб за попередньою змовою (організована група або злочинна організація) як обтяжуючу обставину, яка обов'язково враховується судом при призначенні покарання. Натомість, вчинення злочину злочинною організацією, окремо не визначено як обтяжуючу обставину. За вчинення злочину в складі злочинної організації передбачено кримінальну відповідальність за ст. 255 КК України.

В Загальній частині КК України, окрім визначення та обтяжуючих обставин, вказується на пом'якшуючи обставини та обставини, які виключають злочинність діяння, як-от: вимушене заподіяння шкоди правоохоронюваним інтересам особою, яка відповідно до закону виконувала спеціальне завдання, беручи участь в організованій групі чи злочинній організації з метою попередження чи розкриття їх злочинної діяльності, - виконання спеціального завдання з попередження чи розкриття злочинної діяльності організованої групи чи злочинної організації (ст. 43 КК України).

Так, особа, зазначена у частині першій зазначеної статті, підлягає кримінальній відповідальності лише за вчинення у складі організованої групи чи злочинної організації особливо тяжкого злочину, вчиненого умисно і поєднаного з насильством над потерпілим, або тяжкого злочину, вчиненого умисно і пов'язаного з спричиненням тяжкого тілесного ушкодження потерпілому або настанням інших тяжких або особливо тяжких наслідків [3].

Також в КК України визначаються обставини, які пом'якшують покарання, визначені п. 9 ч. 1 ст. 66 КК України, а саме: виконання спеціального завдання з попередження чи розкриття злочинної діяльності організованої групи чи злочинної організації, поєднане з вчиненням злочину у випадках, передбачених КК України [3].

Пленум Верховного Суду України у Постанові «Про практику розгляду судами кримінальних справ про злочини, вчинені стійкими злочинними об'єднаннями», у п. 9, надає визначення організованої групи (ч. 3 ст. 28), під якою належить розуміти внутрішньо стійке об'єднання трьох і більше осіб, яке було попередньо утворене з метою вчинення ряду злочинів або тільки одного, який потребує ретельної довготривалої підготовки. Таку групу слід вважати утвореною з моменту досягнення iї учасниками домовленості про вчинення першого злочину за наявності планів щодо подальшої спільної злочинної діяльності [4]. 
Визначення злочинної організації наведено у п. 10 зазначеної Постанови, відповідно до якого «Злочинна організація (ч. 4 ст. 28 КК) - це внутрішньо й зовнішньо стійке ієрархічне об'єднання трьох і більше осіб або двох і більше організованих груп (структурних частин), метою діяльності якого є вчинення тяжких або особливо тяжких злочинів чи тільки одного, що вимагає ретельної довготривалої підготовки, або керівництво чи координація злочинної діяльності інших осіб, або забезпечення функціонування як самої злочинної організації, так і інших злочинних груп» [4].

Аналіз Особливої частини КК України.

В Розділі I «Злочини проти основ Національної безпеки України»2 склади: ч. 3 ст. 109 КК - Дії, спрямовані на насильницьку зміну чи повалення конституційного ладу або на захоплення державної влади за вчинення таких дій організованою групою; ч. 4 ст. $110^{2}$ - Фінансування дій, вчинених з метою насильницької зміни чи повалення конституційного ладу або захоплення державної влади, зміни меж території або державного кордону України - за фінансування таких дій вчинені ОГ.

В Розділі II «Злочини проти життя та здоров'я особи» 1 склад: ч. 2 ст. 129 - Погроза вбивством.

В Розділі ІІІ «Злочини проти волі, честі та гідності особи» 4 склади: ч. 3 ст. 146 КК - Незаконне позбавлення волі або викрадення людини; ч. 3 ст. 149 КК - Торгівля людьми; ч. 3 ст. 150 КК - Експлуатація дітей; ч. 3 ст. 1501 КК - Використання малолітньої дитини для заняття жебрацтвом.

В Розділі V «Злочини проти виборчих, трудових та інших особистих прав і свобод людини і громадянина» 4 склади: ч. 4 ст. $159^{1}$ КК Порушення порядку фінансування політичної партії, передвиборної агітації, агітації з всеукраїнського або місцевого референдуму; ч. 3 ст. 161 КК - Порушення рівноправності громадян залежно від їх расової, національної належності, релігійних переконань, інвалідності та за іншими ознаками; ч. 3 ст. 176 КК - Порушення авторського права i суміжних прав; ч. 3 ст. 177 КК - Порушення прав на винахід, корисну модель, промисловий зразок, топографію інтегральної мікросхеми, сорт рослин, раціоналізаторську пропозицію.

В Розділі VI «Злочини проти власності» 6 складів злочинів: ч. 5 ст. 185 КК - Крадіжка; ч. 5 ст. 186 КК - Грабіж; ч. 4 ст. 187 - Роз- 
бій; ч. 4 ст. 189 КК - Вимагання; ч. 4 ст. 190 КК - Шахрайство; ч. 5 ст. 191 КК - Привласнення, розтрата майна або заволодіння ним шляхом зловживання службовим становищем.

В Розділі VII «Злочини проти господарської діяльності» 7 складів злочинів: ч. 3 ст. 199 КК - Виготовлення, зберігання, придбання, перевезення, пересилання, ввезення в Україну з метою використання при продажу товарів, збуту або збут підроблених грошей, державних цінних паперів, білетів державної лотереї, марок акцизного податку чи голографічних захисних елементів; ч. 3 ст. 2011 КК - Переміщення через митний кордон України поза митним контролем або з приховуванням від митного контролю лісоматеріалів або пиломатеріалів цінних та рідкісних порід дерев, лісоматеріалів необроблених, а також інших лісоматеріалів, заборонених до вивозу за межі митної території України; ч. 3 ст. 206 КК - Протидія законній господарській діяльності; ч. 3 ст. 209 КК - Легалізація (відмивання) доходів, одержаних злочинним шляхом; ч. 3 ст. 224 КК - Виготовлення, збут та використання підроблених недержавних цінних паперів; ч. 3 ст. 229 КК - Незаконне використання знака для товарів і послуг, фірмового найменування, кваліфікованого зазначення походження товару; ч. 4 ст. $232^{1}$ КК Незаконне використання інсайдерської інформації.

В Розділі IX «Злочини проти громадської безпеки» 4 склади злочинів: ст. 255 КК - Створення злочинної організації; ч. 3 ст. $258^{-5}$ КК Фінансування тероризму; ч. 3 ст. 262 КК - Викрадення, привласнення, вимагання вогнепальної зброї, бойових припасів, вибухових речовин чи радіоактивних матеріалів або заволодіння ними шляхом шахрайства або зловживанням службовим становищем; ч. 3 ст. $263^{1}$ КК Незаконне виготовлення, переробка чи ремонт вогнепальної зброї або фальсифікація, незаконне видалення чи зміна ï маркування, або незаконне виготовлення бойових припасів, вибухових речовин чи вибухових пристроїв.

В Розділі XI «Злочини проти безпеки руху та експлуатації транспорту» 4 склади злочинів: ч. 3 ст. 278 КК - Угон або захоплення залізничного рухомого складу, повітряного, морського чи річкового судна; ч. 3 ст. 280 КК - Примушування працівника транспорту до невиконання своїх службових обов'язків; ч. 3 ст. 289 КК - Незаконне заволодіння транспортним засобом; ч. 3 ст. 292 КК - Пошкодження об'єктів 
магістральних або промислових нафто-, газо-, конденсатопроводів та нафтопродуктопроводів.

Розділ XII «Злочини проти громадського порядку та моральності» 2 склади злочинів: ч. 2 ст. 302 КК - Створення або утримання місць розпусти і звідництво; ч. 3 ст. 303 КК - Сутенерство або втягнення особи в заняття проституцією.

Розділ XIII «Злочини у сфері обігу наркотичних засобів, психотропних речовин, їх аналогів або прекурсорів та інші злочини проти здоров'я населення» 7 складів: ч. 3 ст. 305 КК - Контрабанда наркотичних засобів, психотропних речовин, їх аналогів чи прекурсорів або фальсифікованих лікарських засобів; ч. 3 ст. 307 КК - Незаконне виробництво, виготовлення, придбання, зберігання, перевезення, пересилання чи збут наркотичних засобів, психотропних речовин або їх аналогів; ч. 3 ст. 308 КК - Викрадення, привласнення, вимагання наркотичних засобів, психотропних речовин або їх аналогів чи заволодіння ними шляхом шахрайства або зловживання службовим становищем; ч. 3 ст. 311 КК - Незаконне виробництво, виготовлення, придбання, зберігання, перевезення чи пересилання прекурсорів; ч. 3 ст. 312

КК - Викрадення, привласнення, вимагання прекурсорів або заволодіння ними шляхом шахрайства або зловживання службовим становищем; ч. 3 ст. 313 КК - Викрадення, привласнення, вимагання обладнання, призначеного для виготовлення наркотичних засобів, психотропних речовин або їх аналогів, чи заволодіння ним шляхом шахрайства або зловживання службовим становищем та інші незаконні дії 3 таким обладнанням; ч. 4 ст. 321 КК - Незаконне виробництво, виготовлення, придбання, перевезення, пересилання, зберігання з метою збуту або збут отруйних чи сильнодіючих речовин або отруйних чи сильнодіючих лікарських засобів.

В Розділі XIV «Злочини у сфері охорони державної таємниці, недоторканості державних кордонів, забезпечення призову та мобілізації» 3 склади злочинів: ч. 3 ст. 332 КК - Незаконне переправлення осіб через державний кордон України; ч. 3 ст. $332^{1} \mathrm{KK}-$ Порушення порядку в'їзду на тимчасово окуповану територію України та виїзду з неї; ч. 2 ст. 333 КК - Порушення порядку здійснення міжнародних передач товарів, що підлягають державному експортному контролю. 
В Розділі XV «Злочини проти авторитету органів державної влади, органів місцевого самоврядування, об'єднань громадян та злочини проти журналістів» 4 склади злочинів: ч. 4 ст. 345 КК - Погроза або насильство щодо працівника правоохоронного органу; ч. 4 ст. $345^{1}$ КК Погроза або насильство щодо журналіста; ч. 3 ст. 355 КК - Примушування до виконання чи невиконання цивільно-правових зобов'язань; ч. 3 ст. 359 КК - Незаконні придбання, збут або використання спеціальних технічних засобів отримання інформації.

В Розділі XVII «Злочини у сфері службової діяльності та професійної діяльності, пов'язаної з наданням публічних послуг» 3 склади злочинів: ч. 2 ст. 3683 КК - Підкуп службової особи юридичної особи приватного права незалежно від організаційно-правової форми; ч. 2 ст. $368^{4}$ КК - Підкуп особи, яка надає публічні послуги; ч. 4 ст. 369 КК Пропозиція, обіцянка або надання неправомірної вигоди службовій особі.

В Розділі XVIII «Злочини проти правосуддя» одна стаття: ст. 392 КК - Дії, що дезорганізують роботу установ виконання покарань.

В Розділі XX «Злочини проти миру, безпеки людства та міжнародного правопорядку» один склад злочину: ч. 2 ст. $436^{1} \mathrm{KK}-$ Виготовлення, поширення комуністичної, нацистської символіки та пропаганда комуністичного та націонал-соціалістичного (нацистського) тоталітарних режимів [2].

Таким чином, аналіз диспозицій статей Кримінального кодексу України дає змогу зазначити, що Особлива частина КК України налічує всього 51 статтю, в якій, в якості кваліфікуючих ознак визначено організацію організованої групи, участь в такій групі, фінансування такої групи та інше. Окрім того, окремо закріплено два склади злочинів, які самостійно визначають створення злочинної організації, ст. 255, 392 КК України. Найбільша кількість кваліфікуючих ознак організованої злочинності міститься в розділах: VII Злочини проти господарської діяльності, XIII Злочини у сфері обігу наркотичних засобів, психотропних речовин, їх аналогів або прекурсорів та інші злочини проти здоров'я населення - по 7 статей; VI Злочини проти власності - 6 статей.

Тож постає питання про наявний стан вчинених злочинів у складі організованої злочинності в Україні. 


\section{4. Статистичні данні щодо стану розслідування кримінальних правопорушень}

За2016 рікзакінчено кримінальних проваджень по кримінальним правопорушенням, вчинених організованимигрупамитазлочинними організаціями-136, застаттями: ст. 255 ККС творення злочинноїорганізації-4; ст. 257 КК Бандитизм - 9; ст. 115 КК Умисне вбивство - 4; ст. 187 КК Розбій - 97; ст. 186 КК Грабіж - 19; ст. 189 КК Вимагання - 16, в тому числі одне вчинене організованою групою; ст. ст. 262, 263 КК Незаконний обіг зброї - 18; ст. ст. 305 - 327 КК Злочини у сфері обігу наркотичних засобів, психотропних речовин, їх аналогів та прекурсорів - 157; ст. 185 Крадіжка - 193; ст. 191 КК Привласнення, розтрата майна або заволодіння ним, шляхом зловживання службовим становищем - 14; ст. 204 КК Незаконне виготовлення, зберігання, збут або транспортування 3 метою збуту підакцизних товарів - 14; ст. 209 КК Легалізація (відмивання) доходів, одержаних злочинним шляхом - 18; ст. 212 КК Ухилення від сплати податків, зборів (обов'язкових платежів) - 8; ст. 368 КК Прийняття пропозиції, обіцянки або отримання неправомірної вигоди -18 [1].

У 2017 році закінчено кримінальних проваджень по кримінальним правопорушенням, вчинених організованими групами та злочинними організаціями - 210, за статтями:

1) ст. 255 КК Створення злочинної організації - 5;

2) ст. 257 КК Бандитизм - 14;

3) ст. 115 КК Умисне вбивство - 2;

4) ст. 187 КК Розбій - 81, в тому числі вчинений злочинною організацією - 4;

5) ст. 186 КК Грабіж - 49;

6) ст. 189 КК Вимагання - 21;

7) ст. ст. 262, 263 КК Незаконний обіг зброї - 12;

8) ст. ст. 305 - 327 КК Злочини у сфері обігу наркотичних засобів, психотропних речовин, їх аналогів та прекурсорів - 339, в тому числі членами злочинної організації - 17;

9) ст. 185 Крадіжка - 202;

10) ст. 191 КК Привласнення, розтрата майна або заволодіння ним, шляхом зловживання службовим становищем - 34; 
11) ст. 204 КК Незаконне виготовлення, зберігання, збут або транспортування з метою збуту підакцизних товарів - 48;

12) ст. 209 КК Легалізація (відмивання) доходів, одержаних злочинним шляхом - 6;

13) ст. 212 КК Ухилення від сплати податків, зборів (обов'язкових платежів) - 6;

14) ст. 368 КК Прийняття пропозиції, обіцянки або отримання неправомірної вигоди - 7 [1].

У 2018 році закінчено кримінальних проваджень по кримінальним правопорушенням, вчинених організованими групами та злочинними організаціями - 288, за статтями:

1) ст. 255 КК Створення злочинної організації - 11;

2) ст. 257 КК Бандитизм - 20;

3) ст. 115 КК Умисне вбивство - 16;

4) ст. 187 КК Розбій - 77, в тому числі вчинений злочинною організацією - 4;

5) ст. 186 КК Грабіж - 5;

6) ст. 189 КК Вимагання - 45, в тому числі одне вчинене організованою групою - 1 ;

7) ст. ст. 262, 263 КК Незаконний обіг зброї - 26, у тому числі вчинені у складі злочинної організації - 3;

8) ст. ст. 305 - 327 КК Злочини у сфері обігу наркотичних засобів, психотропних речовин, їх аналогів та прекурсорів - 743, в тому числі членами злочинної організації - 34;

9) ст. 185 Крадіжка - 139;

10) ст. 191 КК Привласнення, розтрата майна або заволодіння ним, шляхом зловживання службовим становищем - 221;

11) ст. 204 КК Незаконне виготовлення, зберігання, збут або транспортування з метою збуту підакцизних товарів - 44;

12) ст. 209 КК Легалізація (відмивання) доходів, одержаних злочинним шляхом - 12;

13) ст. 212 КК Ухилення від сплати податків, зборів (обов'язкових платежів) - 7;

14) ст. 368 КК Прийняття пропозиції, обіцянки або отримання неправомірної вигоди - 6 [1]. 
У 2019 році закінчено кримінальних проваджень по кримінальним правопорушенням, вчинених організованими групами та злочинними організаціями - 293, за статтями:

1) ст. 255 КК Створення злочинної організації - 14;

2) ст. 257 КК Бандитизм - 5;

3) ст. 115 КК Умисне вбивство - 3;

4) ст. 187 КК Розбій - 45, в тому числі вчинений злочинною організацією - 3;

5) ст. 186 КК Грабіж - 55;

6) ст. 189 КК Вимагання - 58, в тому числі одне вчинене організованою групою - 5;

7) ст. ст. 262, 263 КК Незаконний обіг зброї - 9;

8) ст. ст. 305 - 327 КК Злочини у сфері обігу наркотичних засобів, психотропних речовин, їх аналогів та прекурсорів - 818, в тому числі членами злочинної організації - 75 , у тому числі у складі злочинної організації - 52;

9) ст. 185 Крадіжка - 179;

10) ст. 191 КК Привласнення, розтрата майна або заволодіння ним, шляхом зловживання службовим становищем - 85;

11) ст. 204 КК Незаконне виготовлення, зберігання, збут або транспортування з метою збуту підакцизних товарів - 44;

12) ст. 209 КК Легалізація (відмивання) доходів, одержаних злочинним шляхом - 8;

13) ст. 212 КК Ухилення від сплати податків, зборів (обов'язкових платежів) - 10;

14) ст. 368 КК Прийняття пропозиції, обіцянки або отримання неправомірної вигоди - 71 [1].

Таким чином, ми можемо побачити як за останні чотири роки змінився розподіл вчинюваних злочинів організованими групами та злочинними організаціями. Так, найменшу кількість склали злочини за ст. 255 КК України, позитивну динаміку можемо спостерігати щодо розбійних нападів, а от щодо вимагання та незаконного поводження зі зброєю, то навпаки, - невелике збільшення. Однак, найбільша кількість вчинюваних злочинів ОГ та 30 - це злочини пов'язані з незаконним обігом наркотичних засобів, психотропних речовин, їх аналогів та прекурсорів. Тож, вочевидь, на відміну від попередніх років, органі- 


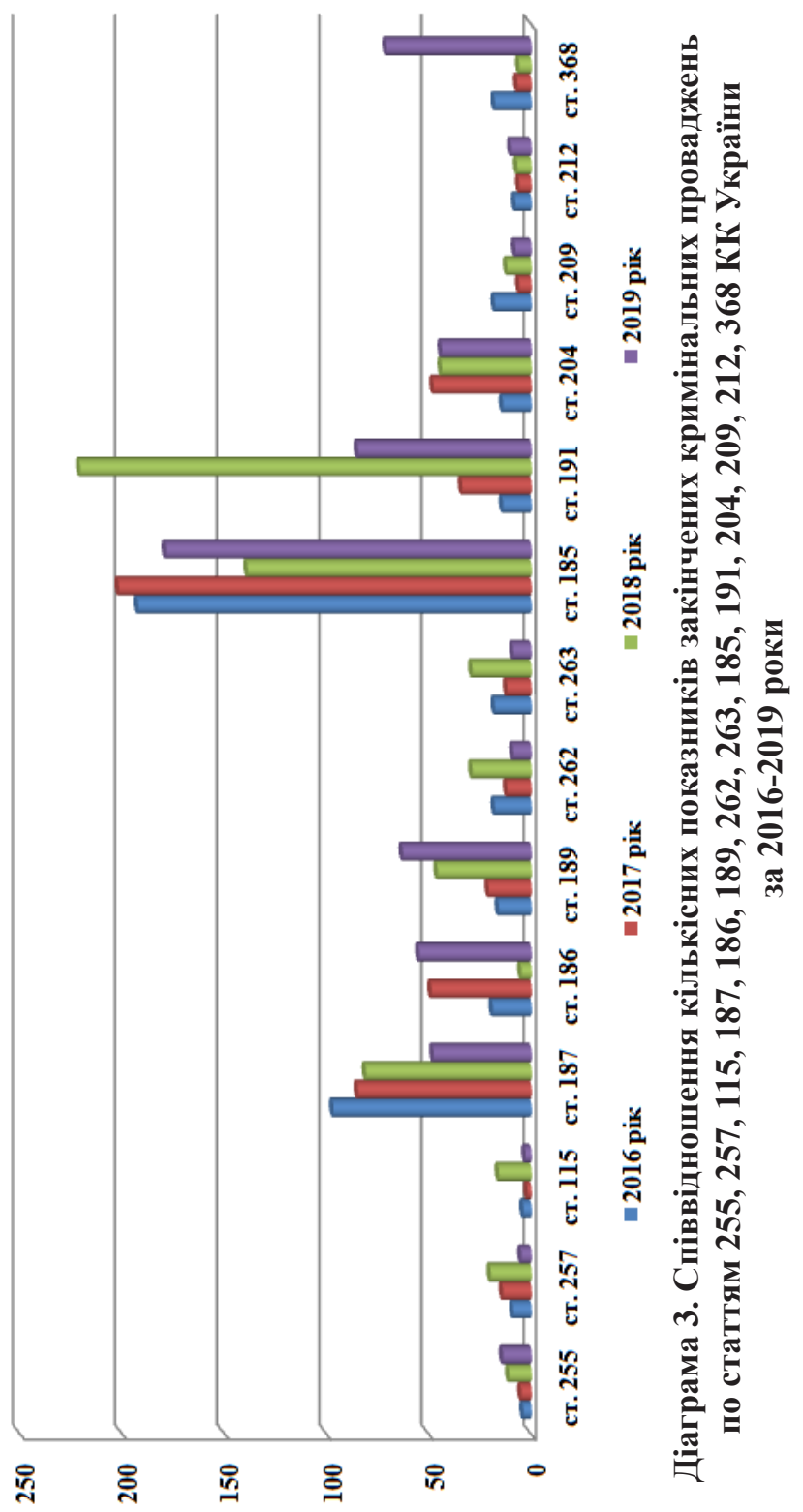




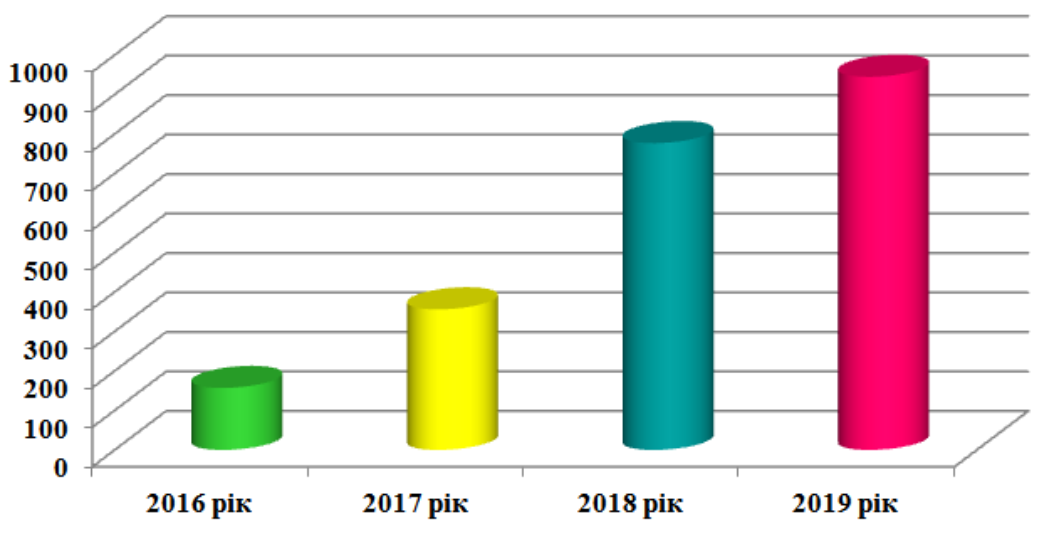

Діаграма 4. Співвідношення кількісних показників закінчених кримінальних проваджень по статтям 305-327 КК України за 2016-2019 роки

зована злочинність трансформувалася з насильницької, агресивно-насильницької, корисливо-насильницької до злочинності в економічній, промисловій сферах. Також, акцентуємо увагу на тому, що найбільшу кількість складає участь та контроль, отримання значної частки прибутку від наркобізнесу.

Слід зазначити, що збільшення кількості злочинів у сфері господарської діяльності (ст.ст. 204, 209, 212 КК України), говорить про трансформацію організованої злочинності в економічну злочинність. Дослідження статистичних даних, розподілу вчинених злочинів у складі ОГ та 30, з урахуванням динаміки, вказує на необхідність проведення заходів протидії організованій злочинності. За досліджуваний період у складі ОГ та 30 було вчинено 59 злочинів, передбачених ст. 205 КК України (Фіктивне підприємництво), яку на сьогодні декриміналізовано.

Цифрова економіка активно працює майже у всіх сферах життєдіяльності, зокрема у хмарних технологіях, Інтернет-банкінгу, у сфері придбання товарів з використанням смартфону, он-лайн консультації тощо. Наявна нормативна база не може забезпечити належний рівень протидії технологічним злочинам. На цьому тлі чисельність скоєних 
злочинів у сфері IT-технологій постійно зростає. Враховуючи викладене, видається доцільним сконцентрувати увагу на таких актуальних питаннях комплексної протидії організованій злочинності у сфері цифрової економіки. Спільний характер проблем протидії злочинності у сфері цифрової економіки як в Україні, так і за кордоном дозволяє зробити висновок про необхідність акумуляції та аналізу позитивного досвіду зарубіжних країн у цій площині. Злочинність у сфері цифрової економіки має транскордонний характер, а тому заходи щодо протидії такій злочинності передбачають налагодження, перш за все, ефективного міжнародного співробітництва організаційно-правового та технічного характеру. До ефективних засобів протидії злочинності у сфері цифрової економіки можна віднести: перманентну модернізацію програмного забезпечення комп'ютерних систем правоохоронних органів; суцільну інтеграцію заходів посилення інформаційної безпеки на основі новітніх розробок та впровадження сучасних систем захисту інформації; створення відповідної нормативно-правової бази, здатної забезпечити протидію сучасним кіберзагрозам [5].

За останні роки в світі гостро стоїть питання протидії кіберзлочинності. Оскільки, як ми могли побачити, КК України у Розділі XVI «Злочини у сфері використання електронно-обчислювальних машин (комп'ютерів), систем та комп'ютерних мереж і мереж електрозв'язку» (ст.ст. 361-363 ${ }^{1}$ КК України) не передбачено ознаку вчинення злочинів організованими групами або злочинними організаціями, тому статистичні дані відсутні, і зазначити який стан кіберзлочинності вчинених ОГ або 30 ми не можемо.

\section{5. Протидія організованій злочинності}

Відповідно до Закону України «Про заходи протидії незаконному обігу наркотичних засобів, психотропних речовин і прекурсорів та зловживанню ними» до заходів протидії незаконному обігу наркотичних засобів психотропних речовин відносять: контрольовану поставку; оперативну закупку; конфіскацію; запити правоохоронних органів про розміщення коштів, одержаних від незаконного обігу наркотичних засобів, психотропних речовин і прекурсорів; огляд транспортних засобів, вантажів і особистих речей громадян; зупинення та припинення діяльності закладів масового перебування громадян, 
у яких виявлені факти вживання чи збуту наркотичних засобів, психотропних речовин або їх аналогів; заходи протидії незаконному культивуванню наркотиковмісних рослин; здійснення адміністративного нагляду за особами, звільненими 3 місць позбавлення волі. Окремо виділено заходи протидії незаконному (немедичному) вживанню наркотичних засобів, психотропних речовин та їх аналогів населенням. Однак, в Законі не вказано про окремі заходи протидії з організованою злочинністю, хоча, як ми можемо побачити зі статистики, такі заходи є необхідними [6].

Стрімкий розвиток цифрових технологій у світі привів до збільшення кількості кіберберзлочинів. Поширюються випадки незаконного збирання, зберігання, використання, знищення, поширення персональних даних, незаконних фінансових операцій, крадіжок та шахрайства у мережі Інтернет. Кіберзлочинність стає транснаціональною та здатна завдати значної шкоди інтересам особи, суспільства і держави [7].

Так, стаття 3 Закону вказує на основні завдання боротьби з організованою злочинністю, а саме: створення загальних правових і організаційних засад у сфері боротьби з організованою злочинністю, сприяння іiі попередженню та ліквідації; визначення системи державних органів, що ведуть боротьбу з організованою злочинністю, та їх взаємовідносин; встановлення повноважень спеціальних державних органів по боротьбі з організованою злочинністю та спеціальних заходів, що здійснюються ними; встановлення обов'язків інших державних органів у сфері боротьби з організованою злочинністю; правове забезпечення фінансових, матеріально-технічних та інших умов, необхідних для боротьби з організованою злочинністю; забезпечення гарантій прав громадян і юридичних осіб під час здійснення заходів боротьби 3 організованою злочинністю [2].

\section{6. Висновки}

Таким чином, дослідження стану організованої злочинності в Україні надає змогу зробити наступні висновки. Частка організованої злочинності в Україні, порівняно із загальною кількістю вчинених злочинів, є невеликою. Зокрема, це може вказувати на активність проведених заходів боротьби з організованою злочинністю державними 
органами, на які відповідно до закону покладено таке завдання. Також, про це може говорити збільшення кількості осіб, яких було притягнуто до кримінальної відповідальності за організацію, участь та злочинну діяльність у складі ОГ та 3О. Однак, викликає занепокоєння поступове збільшення кількості організованих груп та злочинних організацій, за останні роки.

Аналіз вчинюваних злочинів у складі ОГ та 30 показав, що на сьогодні організована злочинність пристосувалася до сучасного світу та трансформувалася. Можемо побачити зниження рівня агресивно-корисливої злочинності - ст.ст. 186, 187, 189 КК України. Найбільшу частку склали злочини, пов'язані з незаконним обігом наркотичних засобів, психотропних речовин, до яких відносяться: контрабанда наркотичних засобів (ст. 305 КК), використання коштів здобутих від незаконного обігу наркотичних засобів та психотропних речовин (ст. 306 КК), незаконний збут наркотичних засобів та психотропних речовин (ст. 307 КК). Поступово збільшується кількість вчинених злочинів у сфері господарської діяльності (ст.ст. 204, 209, 212 КК).

Проведення аналізу КК України щодо притягнення до кримінальної відповідальності за організацію, участь та злочинну діяльність у складі ОГ та 30 показав, що національне кримінальне законодавство передбачає, як обтяжуючу, обставину вчинення злочину в складі організованої групи, участь в діяльності злочинної організації, за що передбачено кримінальну відповідальність ст. 255 КК України. Окрім того, передбачено кваліфікуючі та особливо кваліфікуючі ознаки за організацію, участь та діяльність в ОГ та 3О. Однак, ми не побачили окремої кваліфікації за так звану кіберзлочинність, яку, на нашу думку, можна вважати прогалиною в КК України.

3 урахуванням проведеної кримінологічної характеристики організованої злочинності, іiі кількісних та якісних показників необхідно спланувати заходи протидії організованій злочинності із обов'язковим посиленням уваги в частині протидії наркозлочинності.

Перспективами подальших наукових розробок вбачається проведення детального дослідження осіб, які входили в склад організованих груп та злочинних організацій та формування дієвих заходів протидії організованій злочинності. 


\section{Список літератури:}

1. Офіційні статистичні данні за 2016-2019 роки. Єдиний звіт про кримінальні правопорушення по державі за 2016, 2017, 2018, 2019 років. URL: https://old.gp.gov.ua/ua/stst2011.html?dir_id=112661\&libid=100820 (дата звернення: 18.03.2020).

2. Про організаційно-правові основи боротьби 3 організованою злочинністю : Закон України від 30.06.1993 № 3341-XII. Відомості Верховної Ради України. 1993. № 35. Ст. 358. Дата оновлення: 21.12.2016. URL: https://zakon.rada.gov.ua/laws/show/3341-12 (дата звернення: 25.03.2020).

3. Кримінальний кодекс України : Закон України від 05.04.2001 № 2341-III. Відомості Верховної Ради України. 2001. № 25-26. Ст. 131. Дата оновлення: 17.03.2020. URL: https://zakon.rada.gov.ua/laws/show/2341-14 (дата звернення: 25.03.2020).

4. Про практику розгляду судами кримінальних справ про злочини, вчинені стійкими злочинними об'єднаннями : Постанова Пленуму Верховного суду України від 23.12.2005 № 13. URL: https://zakon.rada.gov.ua/laws/show/ v0013700-05 (дата звернення: 01.04.2020).

5. М. Гребенюк, А. Черняк. Проблеми протидії організованій злочинності у сфері цифрової економіки. Підприємництво, господарство і право. 2019. № 3. C. 297-303.

6. Про заходи протидії незаконному обігу наркотичних засобів, психотропних речовин і прекурсорів та зловживанню ними : Закон України від 15.02.1995 № 62/95-ВР. Відомості Верховної Ради України. 1995. № 10. Ст. 62. Дата оновлення: 14.01.2020. URL: https://zakon.rada.gov.ua/laws/ show/62/95 (дата звернення: 06.04.2020).

7. Про рішення Ради національної безпеки і оборони України від 27 січня 2016 року «Про Стратегію кібербезпеки України» : Указ Президента України від 15.03.2016 № 96/2016. URL: https://zakon.rada.gov.ua/laws/show/96/2016 (дата звернення: 06.04.2020).

\section{References:}

1. Oficijni statystychni danni za 2016-2019 roky. Jedynyj zvit pro kryminaljni pravoporushennja po derzhavi za 2016, 2017, 2018, 2019 rokiv [Official statistics for 2016-2019. The only report on criminal offenses in the state for 2016, 2017, 2018, 2019]. Retrieved from: https://old.gp.gov.ua/ua/stst2011.html?dir id=112661\&libid=100820 (accessed 18.03.2020).

2. Pro orghanizacijno-pravovi osnovy borotjby $\mathrm{z}$ orghanizovanoju zlochynnistju : Zakon Ukrajiny vid 30.06.1993 № 3341-XII [On the organizational and legal basis of the fight against organized crime: Law of Ukraine of 30.06.1993 No 3341-XII]. Vidomosti Verkhovnoji Rady Ukrajiny [Information of the Verkhovna Rada of Ukraine]. 1993, no. 35, pp. 358. Data onovlennja: 21.12.2016. Retrieved from: https://zakon.rada.gov.ua/laws/show/3341-12 (accessed 25.03.2020).

3. Kryminaljnyj kodeks Ukrajiny : Zakon Ukrajiny vid 05.04.2001 № 2341-III [Criminal code of Ukraine: Law of Ukraine dated 05.04.2001 No 2341-III]. 
Vidomosti Verkhovnoji Rady Ukrajiny [Information of the Verkhovna Rada of Ukraine]. 2001, no. 25-26, pp. 131. Data onovlennja: 17.03.2020. Retrieved from: https://zakon.rada.gov.ua/laws/show/2341-14 (accessed 25.03.2020).

4. Pro praktyku rozghljadu sudamy kryminaljnykh sprav pro zlochyny, vchyneni stijkymy zlochynnymy ob'jednannjamy : Postanova Plenumu Verkhovnogho sudu Ukrajiny vid 23.12.2005 № 13 [On the practice of consideration by the courts of criminal cases on crimes committed by persistent criminal associations: Resolution of the Plenum of the Supreme Court of Ukraine of December 23, 2005 No. 13]. Retrieved from: https://zakon.rada.gov.ua/laws/show/v0013700-05 (accessed 01.04.2020).

5. M. Ghrebenjuk, A. Chernjak (2019). Problemy protydiji orghanizovanij zlochynnosti u sferi cyfrovoji ekonomiky [Problems of combating organized crime in the digital economy]. Pidpryjemnyctvo, ghospodarstvo i pravo, no. 3, pp. 297-303.

6. Pro zakhody protydiji nezakonnomu obighu narkotychnykh zasobiv, psykhotropnykh rechovyn i prekursoriv ta zlovzhyvannju nymy Zakon Ukrajiny vid 15.02.1995 № 62/95-VR [On the Measures to Combat Illicit Trafficking of Drugs, Psychotropic Substances and Precursors and their Abuse Law of Ukraine of 15.02.1995 No. 62/95-BP]. Vidomosti Verkhovnoji Rady Ukrajiny [Information of the Verkhovna Rada of Ukraine]. 1995, no. 10, pp. 62. Data onovlennja: 14.01.2020. Retrieved from: https://zakon.rada.gov.ua/laws/show/62/95 (accessed 06.04.2020).

7. Pro rishennja Rady nacionaljnoji bezpeky i oborony Ukrajiny vid 27 sichnja 2016 roku «Pro Strateghiju kiberbezpeky Ukrajiny»: Ukaz Prezydenta Ukrajiny vid 15.03.2016 № 96/2016 [On the decision of the National Security and Defense Council of Ukraine of January 27, 2016 "On the Cybersecurity Strategy of Ukraine": Presidential Decree No. 96/2016 of 15.03.2016]. Retrieved from: https://zakon.rada.gov.ua/laws/show/96/2016 (accessed 06.04.2020). 